\title{
Incomes and Assets of Older Australians: Trends and Policy Implications
}

\author{
Ann Harding, Anthony King and Simon Kelly
}

$\mathrm{T}$ his paper examines trends in the wealth and incomes of older Australians over the 11 years from 1985-86 to 1996-97. The primary data sources for this analysis are the ABS 1986 Income Survey and 1997-98 Survey of Income and Housing Costs 'confidentialised' unit record files. These surveys provide very comprehensive national snapshots of the income, socio-demographic and other characteristics of a representative sample of Australians.

The ABS defines income as 'cash receipts that are regular and recurring' and includes income sources such as wages and salaries, profit and loss from own business, property income, government cash transfers and private cash transfers (such as superannuation and child support) are all included. Receipts that are excluded from income because they are not regular and recurring include inheritances, maturity payments on life insurance policies and capital gains and losses. Imputed rent is not calculated for home owners. Annual cash income is the income measure used.

While income is a flow, wealth is a stock. Both are important when considering the economic position of older Australians. Two older Australians with similar incomes might be in very different positions if one owns no assets but the other has substantial assets to draw upon if and when they are in need.

The ABS surveys provide details of only one type of wealth - the respondent's estimate of the value of their home and the amount of mortgage outstanding on that home. The surveys do not directly provide estimates of the value of other wealth sources, but instead report the income received from such wealth sources (such as interest, rent and dividends). This information has been used by NATSEM to impute estimated wealth holdings for each of the families contained within the survey. For 1986 this utilised the methodology mapped out by Bækgaard (1998) with some later minor adjustments. For 1996-97 the methodology is described in Kelly (2001). The wealth sources included in this study comprise own home, shares, cash, investment properties, own business and accumulated value of superannuation. Other sources, such as consumer durables and cars, are not included. The discounted future value of the government age pension is also not included within our estimates of private wealth holdings.

It must be emphasised that imputing the estimated value of wealth holdings using such capitation methods, whilst a technique frequently employed by researchers in this field (Dilnot, 1990), is nonetheless subject to some degree of

Ann Harding is Professor of Applied Economics and Social Policy at the University of Canberra and the inaugural Director of NATSEM. Anthony King is a Principal Research Fellow at NATSEM. Simon Kelly is the current holder of the NATSEM PhD Scholarship. 
uncertainty. In addition, there may be issues of comparability between the 1986 and 1997-98 Income Surveys. For example, in 1986 the definition of dependent children is somewhat narrower than in 1997-98. In 1997-98 negative business and investment incomes were left untouched by the ABS while, in 1986 they were reset to zero. At this stage we have not amended the data to attempt to standardise for such differences. In addition, some issues have been raised about the comparability of the ABS income surveys over time (given the change in methodology from the mid 1990s surveys onwards), and in a joint project the ABS and the Social Policy Research Centre at the University of NSW are currently examining these issues. It is also important to note that the ABS only surveys those living in private dwellings so that the small proportion of aged persons living, for example, in nursing homes, are not included within the scope of our estimates. Finally, both sampling and non-sampling error affect all sample survey results.

There are a number of possible ways of looking at the economic wellbeing of older Australians. Here we are looking at families categorised by the age of their head. Our 'older Australian' group thus includes a couple where the husband is aged 65 and the wife is aged 60, but may exclude Australians aged over 65 years who live in families where a younger spouse has been categorised as the head. Our families comprise either a single person, a sole parent living with their dependent children, or a couple with or without dependent children.

The focus in this article on trends in the wealth holdings of older Australians complements other recent research into the changing economic circumstances of this group. Whiteford and Bond (2000) examined trends in incomes from 1986 to 1995-96, with consideration too of the role of non-cash benefits, indirect taxes, housing wealth, and the assets of pensioners (see also King, Bækgaard and Harding, 2001). Recent comprehensive estimates of the wealth of older Australians (Bacon 1998) have, however, been for a single point in time. Here, we present estimates of trends in wealth holdings among older Australians.

In considering the policy implications of the trends that emerge, the context is one of considerable policy activity in the area of retirement incomes over the past two decades (see Bateman, 1999; and King, Walker and Harding, 2001, for summaries). The Australian publicly funded pension scheme remains unique internationally, with our age pension being a non-contributory flat-rate meanstested system, with eligibility governed by age and residency criteria. Some 80 per cent of Australians who qualify by age receive either all or a portion of the full age pension.

However, in preparing for more rapid population ageing over the next two decades, successive Australian governments have made several changes to the retirement income system. These changes - which include a shift toward greater self-provision via the compulsory Superannuation Guarantee levied upon employers and, for women, an increase in the age of eligibility of the public pension - are in line with policy shifts observed in many other developed countries. 
The dominance of the public age pension in Australia has until now ensured greater uniformity among the incomes of older persons than is common overseas. An increase in the diversity of the incomes and wealth holdings of older Australians can be expected in the future, as the impact of more comprehensive superannuation in the post-war period bears fruit - and such growing diversity is already apparent over the past decade.

\section{Changes in Wealth}

Our estimates suggest a 62 per cent increase in the real value of total Australian household wealth from the mid 1980s to the late 1990s. Expressed in 1998 dollars, this is an increase from $\$ 1058$ billion in 1986 rising to $\$ 1712$ billion by 1997. How much of this wealth is owned by older Australians? Has their share of wealth increased? Has its composition changed, or are the same types of asset as important now as they were in the mid 1980s? Has the pattern of wealth holdings among older Australians changed?

Figure 1: Estimated Shares of Total Net Australian Household Wealth by Age of Family Reference Person: 1985-86 and 1996-97

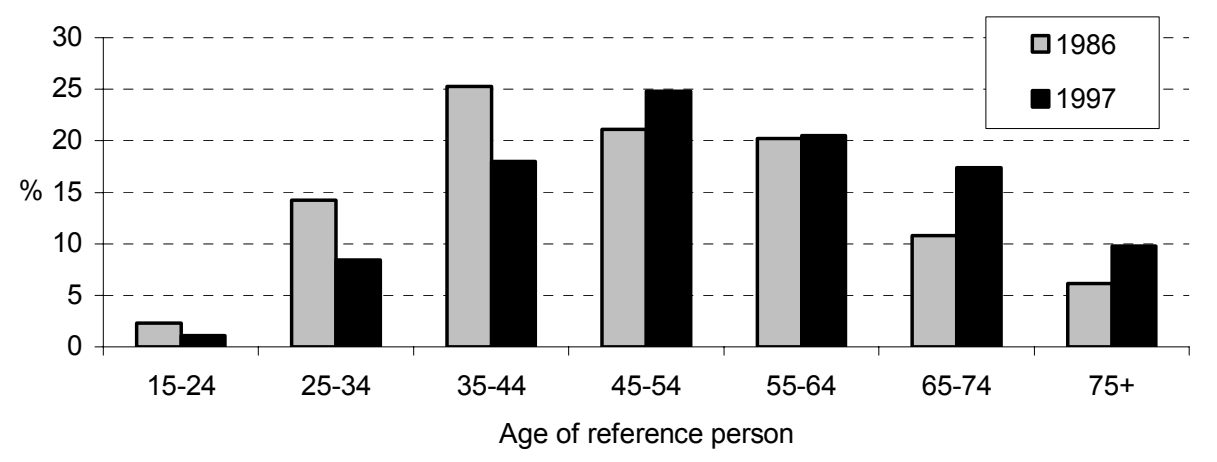

Data source: NATSEM simulations based on unit record data from ABS 1986 Income Distribution Survey and ABS 1997-98 Survey of Incomes and Housing. For the detailed tables upon which this and other figures are based, see Harding, King and Kelly, 2002.

\section{Shares of Total Wealth}

The increasing share of wealth held by older Australians is clearly evident in Figure 1. The distribution of wealth across the population has shifted markedly toward older Australians since the mid 1980s. The share held by those aged 65 or over increased from 17 per cent to 27 per cent between 1986 and 1997. Conversely, younger Australians aged less than 45 years held a declining share of total wealth. 
Now, we know that at the same time the share of the Australian population aged 65 or more has also been increasing. So, how much of this greater share of wealth held by older Australians simply reflects higher population numbers in these age groups? Looking at average wealth per adult provides a much clearer picture and this is done in Figure 2.

Figure 2: Estimated Net Average Wealth per Adult by Age of Family Reference Person: 1985-86 and 1996-97 (June 1998 dollars)

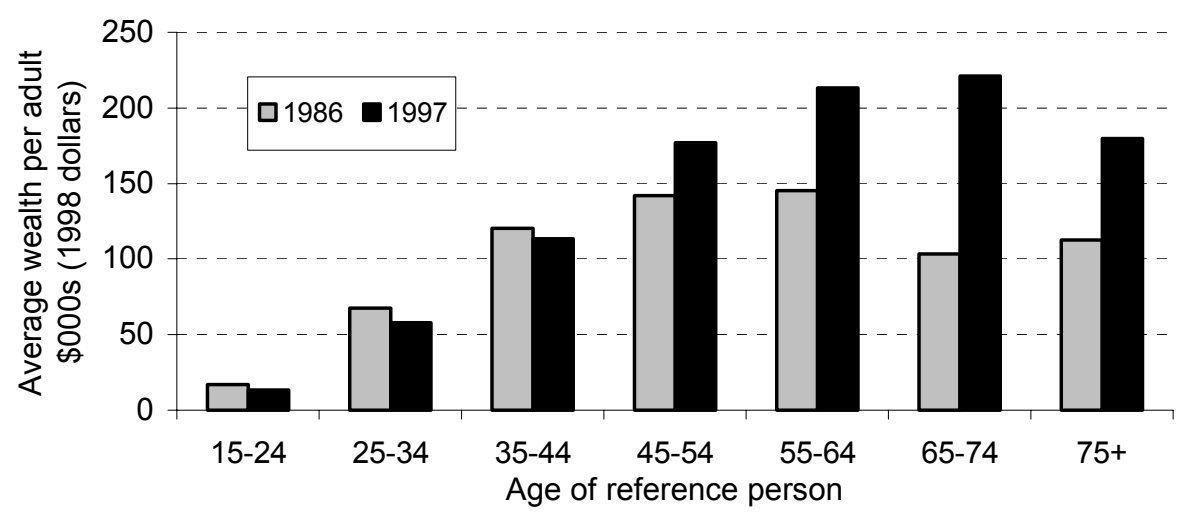

Note: To derive all 'per adult' estimates in this paper, the total wealth of couples has been divided equally between the two partners. Note that all estimates are in June 1998 dollars, with adjustment by the CPI

Data Source: NATSEM simulations based on unit record data from ABS 1986 Income Distribution Survey and ABS 1997-98 Survey of Incomes and Housing.

Figure 2 shows a dramatic change in the picture since the mid 1980s. For those living in families with heads under 45 years old, average wealth per adult actually fell over the period. For those aged 45 years and over, average wealth per adult rose. This increase in wealth was particularly marked for older Australians aged 65 years and over. Average wealth for the 65-74 years age group increased by 115 per cent - from an estimated $\$ 103,000$ in 1986 to $\$ 221,000$ by 1997 . The increase for the 75 and over group was not as high, but still a very substantial 61 per cent - from $\$ 112,000$ in 1986 to $\$ 180,000$ by 1997 . And remember that these figures are in constant June 1998 dollars, so they reflect real increases in wealth and not just the effects of inflation.

Understanding the sort of changing pattern shown in Figure 2 can be quite complicated because it is necessary to disentangle so-called 'age', 'period' and 'cohort' effects. The 'age' effects are those where we see a distinctive pattern to wealth accumulation over the life course - increasing wealth with age until retirement when there is typically some running down of wealth. This broad pattern is exhibited in Figure 2 - though there is a notable difference between 1986 and 1997 in the apparent degree of running down of assets in older age. 
'Period' effects are those that reflect different conditions prevailing at different times. For example, the returns on investments, taxation regimes, and the ease of access to home-ownership vary over time. People's wealth accumulation will clearly be affected by the conditions prevailing over different stages of their life. Finally, 'cohort' effects refer to the possibility of cohorts of the population behaving differently. Thus, people aged in their fifties in the 1970s may well have behaved differently to people aged in their fifties in the 1950s. And we know that there are many such differences - in, for example, family formation, labour force activity and so forth.

The importance of period and cohort effects in the picture of the changing wealth of older Australians is very evident in Figure 2, which gives the impression of a wave moving through the age profile of wealth holdings. In 1986, the peak wealth holding was for the 55-64 year age group. Eleven years later, the peak is observed for the 65-74 year age group. Similarly, the age at which average wealth starts to decline has advanced 10 years over the 11-year period. There is thus a very strong suggestion of important period and cohort effects in the wealth holdings of older Australians. Really, this simply confirms the common sense view that the wealth of older Australians will be largely determined by their behaviour and fortunes earlier in life.

What Figure 2 also shows is that there are significant differences in the behaviour and fortunes of population cohorts. The peak wealth holding is seen for those aged 65-74 years in 1997. This population group was born between 1923 and 1932 and their prime wealth accumulation years coincided with the long postWorld War II economic boom. In 199776 per cent of this cohort owned their homes outright, with the majority thus benefiting from the boom in house prices over the previous decade. The oldest cohort - those aged more than 75 years in 1996 — were born before 1922. The 1930s Depression and World War II coincided with their early adult lives, and they show notably lower wealth holdings in older age than the economically more fortunate cohort that followed.

The cohorts coming after the 'peak' 65-74 year old cohort in 1997 also do not look quite so fortunate, with Figure 2 in particular showing real declines over recent years in average wealth for families with heads aged less than 45 years. Further investigation indicated that this was due to falling home ownership rates and the growing value of mortgages for younger cohorts, rather than to declines in the average price of homes. For example, the proportion of families headed by a 25 to 34 year old who either owned or were purchasing their own home fell from 46 per cent in 1986 to 35 per cent in 1997. For 35 to 44 year olds, the comparable fall was 72 to 62 per cent over the 11 years. Allied with these declining home ownership rates were sharp increases in the real value of mortgages. Together these two factors produced falling real home equity values for under 45 year olds. While families headed by 25 to 44 year olds did enjoy increases in the average value of their shares and accumulated superannuation entitlements, these increases were not sufficient to offset their declining home equity. In contrast, older cohorts experienced sharp increases in the value of their superannuation, shares and homes - hence their rising wealth holdings relative to younger groups in the population. 


\section{Components of Older Australians' Wealth}

What type of assets do older Australians own? Figure 3 shows that their own home remains the most important asset of older Australians. The net average value per adult of such homes among all Australians aged 65 years and over has increased substantially since the mid 1980s, from about $\$ 64,000$ in 1986 to $\$ 87,000$ in 1997 (in 1998 dollars). But despite the continued popularity of the home, other asset classes have shown much more rapid growth among the aged. In 1986 the average superannuation holdings of older Australians were almost non-existent, at less than $\$ 3000$ per adult. By 1997 this had grown rapidly to $\$ 36,000$. Here, it needs to be recognised that the fruits of superannuation appear in different forms in older people's assets, depending on how people take their superannuation benefit. If taken as a lump sum, it may appear, for example, in equities or in interest-bearing deposits. The apparent massive increase in superannuation assets for older Australians will thus partly reflect growing superannuation coverage over the post World War II period, but will mainly reflect the growing likelihood of superannuation benefits being taken as superannuation pensions.

Equities also performed strongly, with the estimated net value of shares directly held by each adult aged 65 years and over quadrupling from about $\$ 7000$ to $\$ 28,000$. Interest on cash deposits also rose. The figures below suggest that older Australians may have become more adventurous about investing in the stock market.

\section{Figure 3: Estimated Net Average Value of Various Assets per Adult} Aged 65 Years and Over: 1985-86 and 1996-97



Data Source: NATSEM simulations based on unit record data from ABS 1986 Income Distribution Survey and ABS 1997-98 Survey of Incomes and Housing. 


\section{Figure 4: Various Asset Classes as a Proportion of Total Net Wealth per Adult Aged 65 Years and Over: 1985-86 and 1996-97}

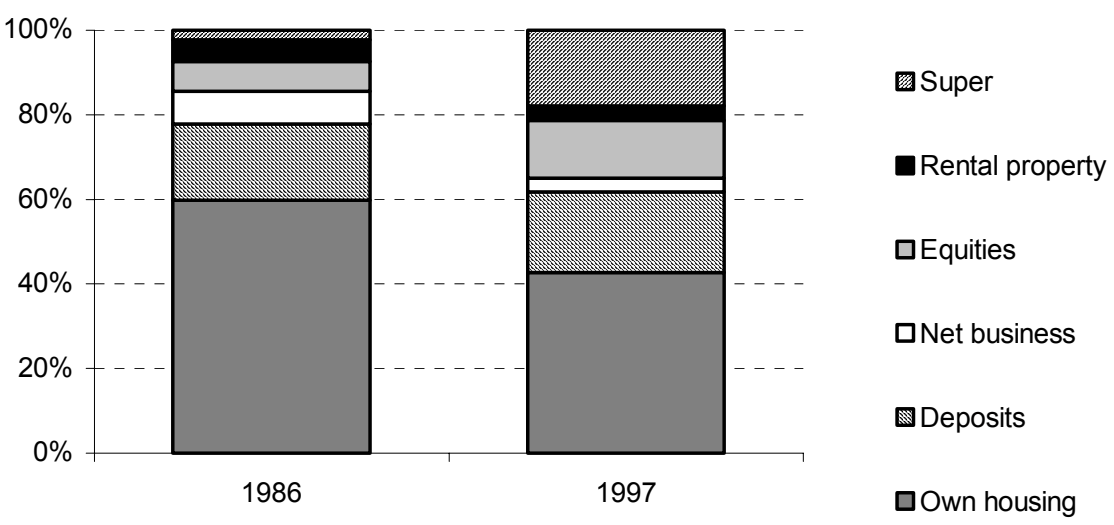

Data Source: NATSEM simulations based on unit record data from ABS 1986 Income Distribution Survey and ABS 1997-98 Survey of Incomes and Housing.

Figure 4 shows the effects of these differential growth rates in the various asset classes on the composition of older Australians' wealth holdings. Direct superannuation assets are now a far more significant component of the total net wealth of older Australians. While superannuation made up only an estimated two per cent of their total wealth in 1986, by 1997 this had risen to almost one-fifth. Equities also became more significant, rising from about 7 to 14 per cent of total wealth over the same period. Despite rising house prices, their own home made up a shrinking proportion of the wealth of older Australians, falling from an estimated 60 per cent of total wealth in 1986 to only 43 per cent by 1997.

\section{Distribution of Older Australians' Wealth}

So far, we have looked at average wealth for older Australians with some distinction only between two age groups - those aged 65-74 years and those aged 75 years and over. How does the picture vary for single males, single females and couples among the population of older Australians? The broad pattern of markedly higher wealth for couples than for singles, and somewhat higher wealth for single males than for single females, has remained consistent over the period. The average wealth level for all three groups grew strongly over the period 1986-1997.

There was, though, some change in the relativities between the wealth levels of couples and single males and females. As a proportion of average wealth for couples, single males' wealth declined from 64 per cent to 59 per cent over the period from 1986 to 1997 . The corresponding figures for single females were 53 per cent falling to 47 per cent. This pattern of changing wealth relativities is partly related to the changing population structure among the population of older 
Australians - for example, the extent to which the different groups include people aged 75 years and over. Another important factor, however, is differences in the composition of the asset holdings of couples, single males and single females (Figure 5). The most marked difference in the composition of wealth holdings is the far higher importance of housing wealth in the assets of older single females, compared to single males and couples.

Figure 5: Asset Classes as a Proportion of Total Net Wealth by Type of Income Unit for Older Australians: 1985-86 and 1996-97

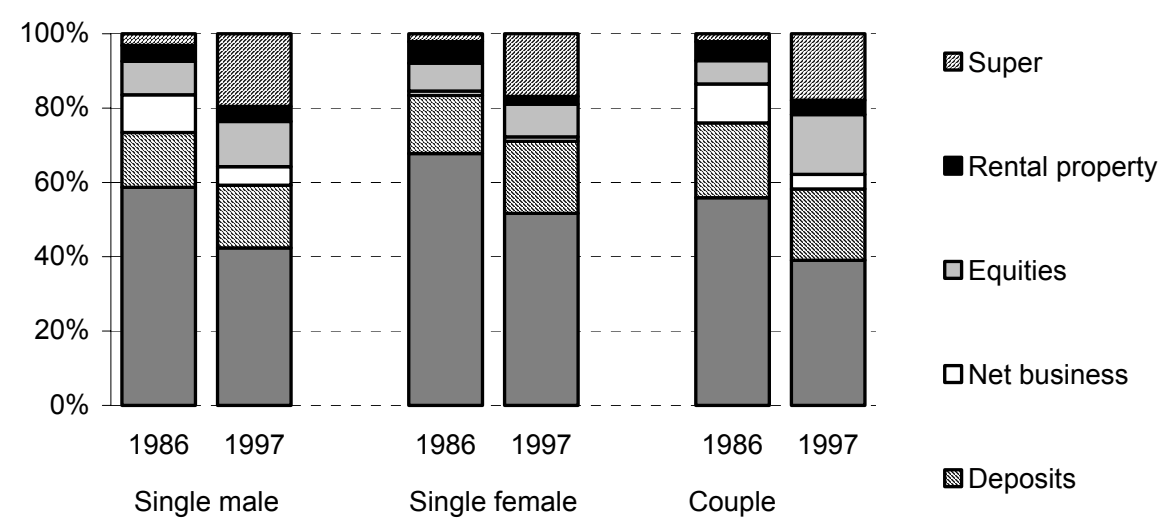

Data Source: NATSEM simulations based on unit record data from ABS 1986 Income Distribution Survey and ABS 1997-98 Survey of Incomes and Housing.

Figure 6: Proportion of Total Wealth Received by Older Australians by Quartile of Wealth: 1985-86 and 1996-97

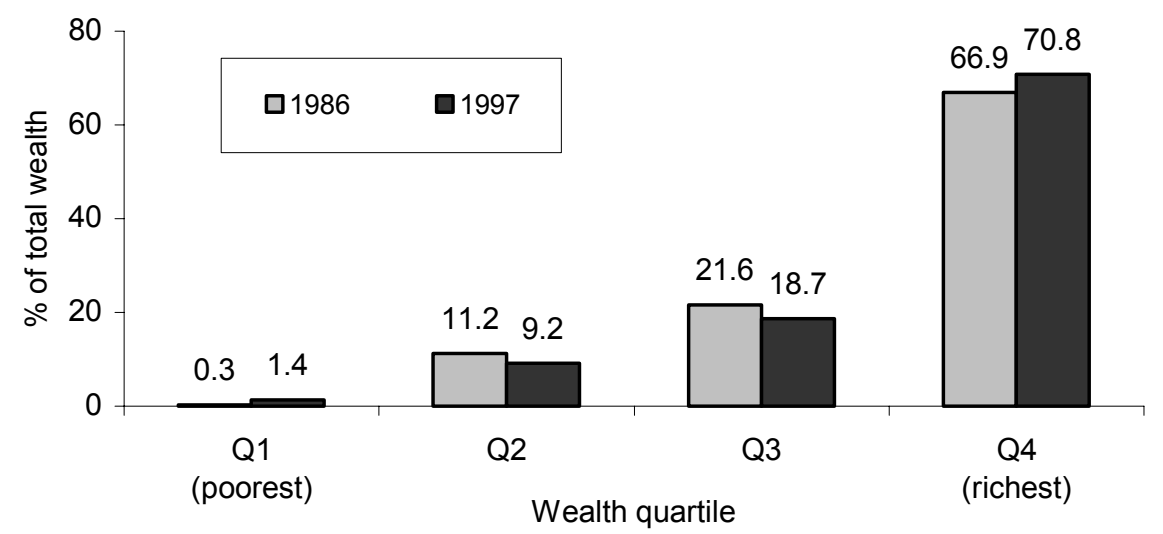

Data Source: NATSEM simulations based on unit record data from ABS 1986 Income Distribution Survey and ABS 1997-98 Survey of Incomes and Housing. 
Another way of looking at wealth distribution is to rank all older Australians by their wealth and then divide them into four equally sized groups - quartiles. Figure 6 suggests that the most profound movement over the 11 years was the strong increase in the share of all older Australians' wealth received by the top 25 per cent - up from about 67 to 71 per cent. The middle half of older Australians suffered a fall in their share of wealth, while the least wealthy one-quarter saw a slight increase in their wealth share.

\section{Changes in Income}

The previous analysis has concentrated upon changes in the net wealth holdings of older Australians. While wealth is an important basis for the economic wellbeing of older Australians, it only provides part of the story. Government benefits notably the Age Pension and Veterans' pensions - play a particularly important role, and labour market activity continues to make a contribution for a few. We turn now to a look at the changing incomes of older Australians, which provides a different perspective upon changes in their economic wellbeing over time.

In the following analysis we have looked at annual disposable income (which is gross income minus income tax). Clearly a single older Australian with an income of $\$ 20,000$ enjoys a different standard of living to an older couple with an income of $\$ 20,000$. To facilitate more accurate comparison between older Australians living in different types of families, we have used the new OECD equivalence scale to calculate 'equivalent incomes'. This scale gives a single adult a value of 1 , a second adult a value of 0.5 and any dependent children a value of 0.3 each. This scale thus assumes that a couple require 50 per cent more income than a single person to reach the same standard of living. (The amount is not double because of 'economies of scale' such as the ability to share housing and heating costs.) The new OECD scale is the scale adopted by Eurostat in its cross-European comparisons.

The equivalent incomes are based on real after-tax incomes to take account of the effect of inflation between 1986 and 1997. As equivalent incomes are a relative rather than absolute measure of income, some form of benchmark is needed. Here, we express the equivalent incomes as an index where the average equivalent income of all those in the 65 years and over age group is set at 1.0.

\section{Overall Incomes}

To look at changes in the fortunes of older Australians we have compared them with families with heads in the 'prime working age groups' (35 to 54 years). This age group has been chosen because it avoids complications in the comparison that can arise from changes in the behaviour of young people and those in the immediate pre-retirement years. The average incomes of older Australians appear to have increased between 1986 and 1997 by slightly more than for those in the peak working years. The estimated increase in equivalent after-tax annual incomes was four percent for older Australians and 1.6 percent for working age 
Australians. (Note that these estimates are after taking out the impact of inflation.) On average, in 1986 the equivalent family incomes of older Australians amounted to 54 per cent of the comparable incomes of families headed by a prime working age Australian. By 1997, this had risen slightly to 55 per cent. This suggests that, on average, older Australians appear to have slightly more than kept pace with rising community incomes.

\section{Changes by Type of Unit}

Have single older Australians fared better or worse than couples over the 11 years? As Figure 8 shows, even after adjusting for needs, older couples on average enjoy higher equivalent incomes than single older Australians. This partly reflects the younger average age of older couples than older singles, and perhaps a different capacity to invest earlier in their lifetime relative to single people.

As expected, older women have lower average incomes than older men about 10 percent lower in 1997 for women than for men. The gap between the economic fortunes of single older men and women has also increased over the 11 years, with the average difference in equivalent disposable incomes rising from 10 percent in 1986 to 12 percent in 1997. The faster growth in single male incomes may reflect a preference for growth assets, as well as more rapidly improving superannuation coverage.

\section{Figure 8: Estimated Mean Equivalent Disposable Incomes of Older Australians by Type of Income Unit: $1985-86$ and 1996-97}

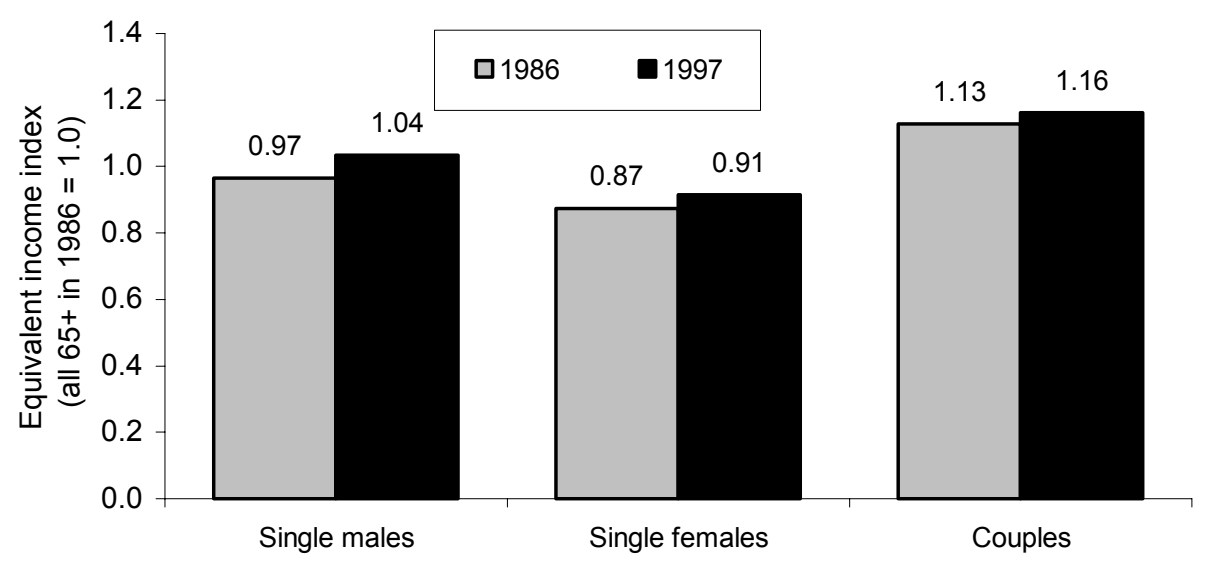

Data Source: ABS 1986 Income Distribution Survey and ABS 1997-98 Survey of Incomes and Housing, 'confidentialised' unit record files.

\section{Changes by Type of Unit and Age}

Figure 9 shows changes in average equivalent incomes of older Australians subdivided by both age and family type. Incomes are generally slightly lower for 
those aged 75 years and over than for the 65-74 year age group. The difference according to age was much more marked for single males in 1986, but has since been much reduced by a strong increase in the average incomes of single males aged 75 years and over.

Figure 9: Equivalent Disposable Incomes of Older Australians by Type of Income Unit and Age of Reference Person: 1985-86 and 1996-97

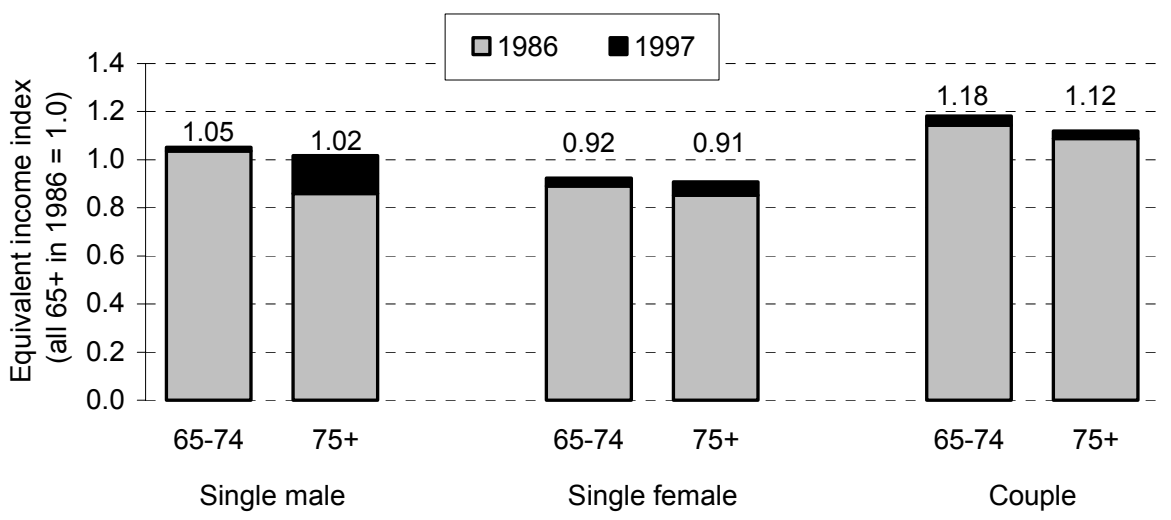

Data Source: ABS 1986 Income Distribution Survey and ABS 1997-98 Survey of Incomes and Housing, 'confidentialised' unit record files.

Figure 10: Proportion of Total Income Received by Older Australians by Quartile of Income - Units with Reference Person Aged 65 Years and Over: 1985-86 and 1996-97

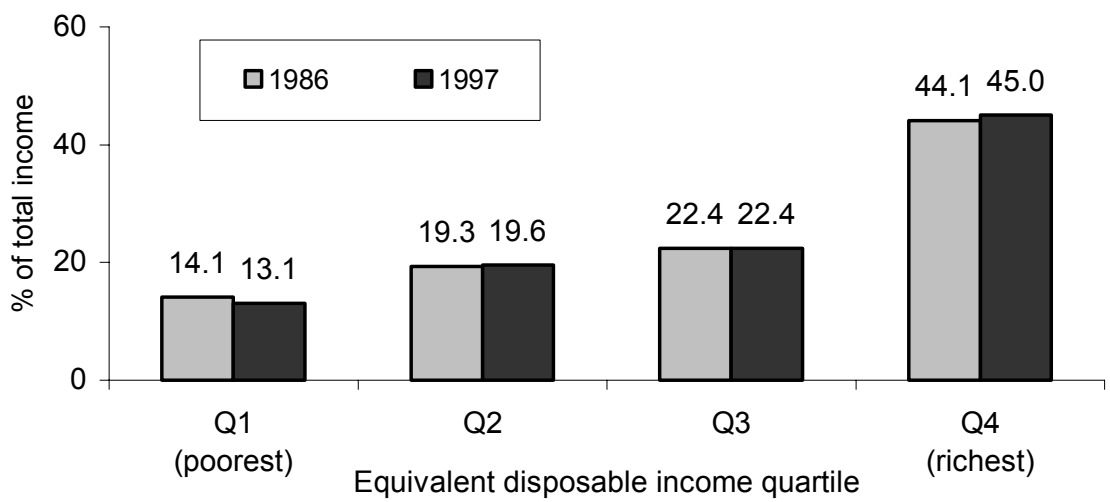

Data Source: ABS 1986 Income Distribution Survey and ABS 1997-98 Survey of Incomes and Housing, 'confidentialised' unit record files. 


\section{Distribution of Older Australians' Incomes}

To look at whether higher or lower income older Australians had fared better, we ranked all Australian families headed by an older Australian by their equivalent disposable income and then divided them into four equally sized groups called quartiles. Figure 10 shows the shares of equivalent disposable income received by each quartile of older Australians. The income share of the bottom quartile of Australians fell slightly over the 11 years, while the shares of the top three quartiles increased or remained constant. The increase was particularly strong for the top quartile. As a result, looking just at these older Australian families, the share of all equivalent disposable income received by the bottom quartile fell from 14.1 to 13.1 per cent over the 11 years, while the share received by the top quartile rose from 44.1 to 45.0 per cent. As with the Australian income distribution more generally (Harding and Greenwell, 2002), we have thus seen rising inequality of incomes over this decade among older Australians.

\section{Government Pensions' Contribution to Incomes of Older Australians}

In 1986, government benefits - mainly the Age Pension — accounted for 62 per cent of the after-tax incomes of older Australians. By 1997, this proportion had fallen to 57 per cent. This does not reflect a reduction in the levels of pension payments, which have been effectively indexed in line with earnings, but rather the growing importance of private retirement incomes. As private retirement incomes have increased, the corresponding fall in the contribution of government benefits is compounded by the impact of means-testing of the pension.

Comparing different family types, single females among the population of older Australians have a notably higher dependence on government benefits than the other groups. In 1997, government benefits accounted for 68 per cent of their incomes, compared to the figures of 55 per cent for single males and 49 per cent for couples. This is a direct reflection of the considerably lesser opportunity that these females had to save for private retirement incomes.

The decrease in the role of government benefits in the incomes of older Australians is evident for all three family types, falling from 61 to 55 per cent over the 11 years for single males, from 72 to 68 per cent for single females and from 54 to 49 per cent for older couples. It is, however, particularly marked for couples and single males aged 65-74 years (Figure 11). These two latter groups are those that have most enjoyed the benefits of post-war increases in superannuation coverage. 


\section{Figure 11: Share of Government Benefits in the Disposable Incomes of Older Australians by Type of Income Unit and Age of Reference Person: 1985-86 and 1996-97}

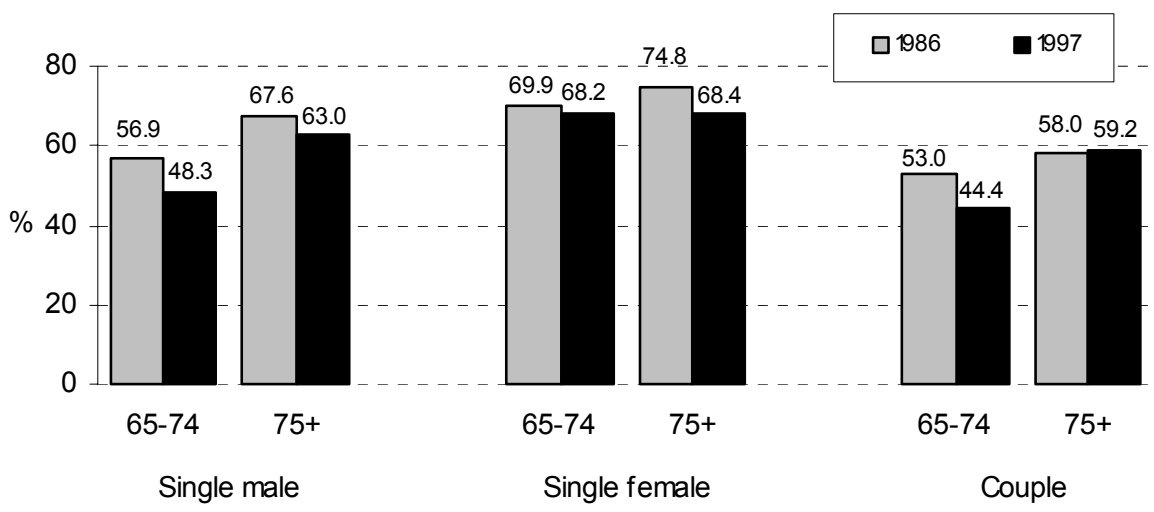

Data Source: ABS 1986 Income Distribution Survey and ABS 1997-98 Survey of Incomes and Housing, 'confidentialised' unit record files.

\section{Policy Implications}

After taking out the impact of inflation, the estimated average wealth of Australians aged 65 years and over rose from $\$ 106,000$ in 1986 to $\$ 204,000$ in 1997 - about a 90 per cent increase. Older Australians have particularly high home ownership rates, and were thus major beneficiaries of the nominal doubling in house prices over this period. Despite this sharp increase in home equity, even stronger growth was experienced in the net value of shares owned and accumulated superannuation benefits among older Australians. As a result, their own home made up a shrinking proportion of the wealth of older Australians, falling from an estimated 60 per cent of total wealth in 1986 to only 43 per cent by 1997.

This profile of growth in average net wealth was in sharp contrast to the fall in the average wealth holdings of Australian families headed by a 15 to 44 year old over the same time period. For example, in 1998 dollars, the average estimated wealth of Australian families with a head aged 25 to 34 years fell from about $\$ 67,000$ in 1986 to $\$ 58,000$ in 1997 . Further investigation revealed that this decline was primarily generated by falling home ownership rates allied with rising home mortgages. Even though the average value of shares and accumulated superannuation benefits for these younger generations had risen, this was more than offset by their falling home equity.

The substantial increase in average wealth among older Australians masked varying outcomes for the most and least wealthy within this group. Considering 
just older Australians, the share of total wealth held by the wealthiest 25 per cent rose from about 67 to 71 per cent.

Moving away from wealth to look at incomes, on average the incomes of older Australians slightly more than kept pace with those of working age Australians over these 11 years. However, the income share of the most affluent quartile of older Australians increased more quickly than those in the middle two quartiles, while the inflation-adjusted income share of the bottom quartile declined. Government cash benefits declined as a share of the after-tax incomes of the aged, from 62 per cent in 1986 to 57 per cent in 1997, reflecting the growing significance of non-pension income sources.

Overall, the results indicated profound inter-generational shifts in the distribution of wealth, with older Australians recording sharp increases in their net wealth and younger Australians reporting net falls. However, the rosy picture for older Australians is affected by the rising fortunes of the wealthiest among this group, with the remaining older Australians not sharing in the economic good fortunes of the wealthiest to the same extent over the 11 years.

Until recently there has been relatively little inequality among older Australians. In previous decades the vast majority were dependent upon the age pension and accumulated wealth levels were relatively low. As a result of the spread of post-war superannuation and the subsequent introduction of the Superannuation Guarantee, allied with substantial asset price rises, this picture of relative equality is starting to change. Our study reveals that there is growing divergence in the economic fortunes of older Australians.

The growing diversity in the economic wellbeing of older Australians raises a number of challenges for policy makers. Most older Australians remain heavily dependent upon the age pension, with increases in the rate of age pension and/or liberalisation of the income and assets tests continuing to be extremely important in determining the living standards of older Australians. However, a slowly growing proportion of older Australians have substantial assets and private incomes, and mechanisms such as reverse mortgages and the extent to which such Australians can pay for services may assume greater prominence in the policy debate as governments grapple with the challenges of financing the health and care costs of older Australians.

Over the next decade or two the large baby boom cohort born after World War II will start retiring. There is extensive debate about whether and to what extent this will increase the fiscal pressures upon government (Kinnear, 2001; Productivity Commission, 1999). Health care costs are likely to loom large in this debate, as changing medical technologies lead to higher medical and pharmaceutical costs (Walker, Percival and Harding, 2000). The extent to which the retiring baby boomers will be able to help finance their health and care costs in their old age will become an increasingly important issue for governments. It is already clear that many older Australians - particularly women - will have relatively limited incomes and wealth to draw upon (Association of Superannuation Funds of Australia, 1999; Kelly, Percival and Harding 2001; King, 2002). However, our study reveals that the older baby boomers, aged 
between about 45 and 52 years in 1997, enjoyed a substantial increase in their average net wealth over the 11 years of this study. Many in this group will have a greater capacity to help finance their future needs in retirement.

As discussed earlier, the generations following the baby boomers have been less successful in building wealth than the boomers were at the same age. We can thus expect growing inter-generational tensions in the future, with the baby boomers supporting higher taxes upon younger generations to help finance their needs in old age, but younger generations questioning whether the boomers can bear a greater share of the financial burden of service provision. Throughout all this, the significance of inheritance is likely to increase. Existing older Australians are wealthier than any previous generation, and the extent to which they run down their assets before death - and who they leave their wealth to will have important policy implications. The taxation of inheritances is also likely to become a more hotly debated issue.

\section{References}

Association of Superannuation Funds of Australia (ASFA) (1999), 'Achieving an Adequate Retirement Income - How Much Is Enough?', ASFA Research Centre, Sydney, October.

Bacon, B. (1998), 'Household Wealth and the Aged - An Income Distribution Survey Analysis', RIM Conference Paper 98/3, The Sixth Colloquium of Superannuation Researchers, University of Melbourne, July.

Bækgaard, H. 1(998), Simulating the Distribution of Household Wealth in Australia: New Estimates for 1986 and 1993, Technical Paper No. 14, National Centre for Social and Economic Modelling, University of Canberra, June.

Bateman, H. (1999), 'Perspectives on Australian Retirement Income Policy', Australian Social Policy 1:31-59.

Dilnot, A. (1990), 'The Distribution and Composition of Personal Sector Wealth in Australia', Australian Economic Review First Quarter:33-40, Institute of Applied Economic and Social Research, Melbourne.

Harding, A. and H. Greenwell (2002), Trends in Income and Expenditure Inequality in the 1980s and 1990s, Discussion Paper No. 56, National Centre for Social and Economic Modelling, University of Canberra, February.

Harding, A., A. King, and S. Kelly (2002), Trends in the Assets and Incomes of Older Australians, Discussion Paper No. 57, National Centre for Social and Economic Modelling, University of Canberra, March.

Kelly, S. (2001), 'Trends in Australian Wealth: New Estimates for the 1990s', Paper presented to the 30th Annual Conference of Economists, University of Western Australia, September.

Kelly, S., R. Percival and A. Harding (2001), 'Women and Superannuation in the 21st Century: Poverty or Plenty?', Paper presented to the SPRC National Social Policy Conference. University of New South Wales, 4-6 July. 
King, A. (2002), Superannuation: The Right Balance, CPA Australia, Melbourne.

King, A., H. Bækgaard and A. Harding (2001), 'Pension Provision in Australia', pp. 48-91 in R. Disney and P. Johnson (eds), Pension Systems and Retirement Incomes Across OECD Countries, Edward Elgar, Cheltenham.

King, A., A. Walker and A. Harding, (2001), 'Perspectives on Australian Retirement Incomes', Australian Economic Review 34(2):155-169.

Kinnear, P. (2001), 'Population Ageing: Crisis or Transition', Discussion Paper No. 45, Australia Institute, December.

Productivity Commission and Melbourne Institute (1999), Policy Implications of the Ageing of Australia's Population, AusInfo, Canberra.

Walker, A., R. Percival and A. Harding (2000), 'The Impact of Demographic and Other Changes on Expenditure on Pharmaceutical Benefits in 2020 in Australia', pp. 149-171 in C. O'Donoghue and H. Sutherland (eds), Microsimulation Modelling for Policy Analysis: Challenges and Innovations, Cambridge University Press, Cambridge

Whiteford, P. and K. Bond (2000), Trends in the Incomes and Living Standards of Older People in Australia, Policy Research Paper No. 6, Department of Family and Community Services, Canberra.

The authors are grateful to George Rothman and two anonymous referees for helpful comments on earlier versions of this work. Aspects of this study have been financed by Australian Research Council Grant No. A79906127. 